\title{
Pengelompokan Diagnosis dan Prosedur Berdasarkan ICD X dan ICD IX di Rumah Sakit Islam Siti Rahmah Padang
}

\author{
Meymi Dwi Okta Reni ${ }^{1)}$, Nurhasanah Nasution ${ }^{2)}$, Rahmi Septia Sari ${ }^{3)}$ \\ Prodi Ilmu Rekam Medis, APIKES Iris Padang, Jln Gajah Mada No. 23 Padang \\ Email : hasanah.nasution11@gmail.com
}

\begin{abstract}
Disease classification system is a grouping of diseases that are similar to the International Statistical Classification of Diseases and Related Health Problems Tenth Revisions (ICD-10) forthe term of diseases and health-related issues. The implementation should be appropriate withICD-10 in order to obtain the accuracy of codes because the results are used to index therecording of diseases. The purpose of this study to identify diagnose classification and procedures based on ICD X and ICD IX at the Islamic Hospital of Siti Rahmah Padang period 01 March - 31 March 2018. This research was using descriptive research methode by collecting data from inpatient data abstraction. The result was showed that mostly diagnosed are Dengue Haemorragis Fever (DHF) as code of ICD XA91 (seven patients) and the most procedures are Chemoterapy as code of ICD IX 99.25 (Five patients) by using cancer diagnoses. The conclution is Deengue Haemorragic Fevers diagnose higher than last year.
\end{abstract}

Key Word: Classification, Diagnose, Procedures, ICD X, ICD IX

\begin{abstract}
Abstrak
Sistem klasifikasi penyakit merupakan pengelompokan penyakit-penyakit yang sejenis dengan International Statistical Classification of Diseases and Related Health Problem Tenth Revisions (ICD-10) untuk istilah penyakit dan masalah yang berkaitan dengan kesehatan. Penerapan pengodean harus sesuai ICD-10 guna mendapatkan kode yang akurat karena hasilnya digunakan untuk mengindeks pencatatan penyakit,. Tujuan penelitian ini adalah untuk mengetahui pengelompokkan diagnosis dan prosedur berdasarkan ICD X Dan ICD IX di Rumah Sakit Islam Siti Rahmah Padang Periode 01 Maret Sampai 31 Maret 2018. Penelitian ini menggunakan jenis penelitian deskriptif dengan cara mengambil data dari abstraksi data pasien rawat inap. Hasil penelitian menunjukkan diagnosis terbanyak didapat adalah Dengue Haemorragic Fever (DHF) dengan kode ICD X A91 sebanyak tujuh pasien dan prosedur terbanyak didapat Chemoterapy dengan kode ICD IX 99.25 sebanyak 5 pasien dengan diagnosis kanker yang berbeda. Kesimpulan: Diagnosis DHF mengalami kenaikan dari tahun sebelumnya.
\end{abstract}

Kata Kunci : Pengelompokan, Diagnosis, Prosedur, ICD X, ICD IX.

\section{PENDAHULUAN}

Rumah Sakit merupakan institusi pelayanan kesehatan bagi masyarakat dengan karateristik tersendiri yang dipengaruhi oleh perkembangan ilmu pengetahuan di bidang kesehatan, teknologi, dan kehidupan sosial ekonomi masyarakat. Rumah sakit harus mampu meningkatkan pelayanan yang lebih bermutu dan terjangkau bagi masyarakat agar terwujudnya derajat kesehatan yang setinggitingginya. (Permenkes No. 269/Per/III/2008).

Peningkatan mutu pelayanan tersebut dapat dilaksanakan apabila pengelolaan rekam medis dan informasi kesehatan terlaksana secara profesional.
Rekam medis merupakan berkas yang berisikan informasi tentang identitas pasien, anamnese, penentuan fisik laboratorium, diagnosis segala pelayanan dan tindakan medik yang diberikan kepada pasien dan pengobatan baik yang dirawat inap, rawat jalan maupun yang mendapatkan pelayanan gawat darurat (Depkes, 2006).

Berkas rekam medis terdapat resume medis yang berisikan segala informasi penting yang berhubungan dengan pasien, salah satu yang terpenting yaitu diagnosis utama pasien, informasi ini menjadi dasar untuk menentukan tindakan yang lebih lanjut dalam upaya pelayanan medis yang lebih baik. 
Menurut Kepmenkes RI Nomor377/Menkes/SK/ III/2007 tentang Standar Profesi Perekam Medis dan Informasi Kesehatan, seorang perekam medis harus mampu menetapkan kode penyakit dan tindakan dengan tepat sesuai klasifikasi yang diberlakukan di Indonesia (ICD-10) tentang penyakit dan tindakan medis dalam pelayanan dan manajemen kesehatan.

Dari uraian tersebut perlu dilakukan penelitian tentang diagnosis dan prosedur yang terbanyak yang terdapat di RS. Siti Rahmah pada periode 01 - 31 Maret 2018. Tujuan dari penelitian ini adalah untuk mengetahui Pengelompokkan Diagnosis Dan Prosedur Berdasarkan ICD X Dan ICD IX Di Rumah Sakit Islam Siti Rahmah Padang Periode 01 Maret Sampai 31 Maret 2018.

\section{METODE}

Jenis penelitian ini adalah metode penelitian deskriptif. Penelitian ini dilakukan pada tanggal 28 Januari sampai 11 Februari 2019. Pengumpulan data tersebut dimulai dengan cara mencatat nomor rekam medis pasien yang pulang sejak tanggal 01 Maret sampai 31 Maret 2018, pencatatan dilakukan berdasarkan buku register pasien rawat inap di Rumah Sakit Islam Siti Rahmah Padang. Setelah pencatatan dilakukan lalu dilakukan abstraksi rekam medis berdasarkan item-item yang diperlukan.

\section{HASIL}

Tabel 1 Pengelompokan Diagnosis Utama Berdasarkan ICD-10

\begin{tabular}{|c|c|c|}
\hline ICD-10 & Arti ICD-10 & Jumlah \\
\hline A91 & Dengue haemorrhagic fever & 17 \\
\hline B51.9 & $\begin{array}{l}\text { Plasmodium vivax malaria without } \\
\text { complication }\end{array}$ & 4 \\
\hline $\mathrm{C} 18.9$ & $\begin{array}{l}\text { Malignant neoplasm of colon, } \\
\text { unspecified }\end{array}$ & 14 \\
\hline $\mathrm{C} 20$ & Malignant neoplasm of rectum & 10 \\
\hline D64.9 & Anaemia, unspecified & 6 \\
\hline E10.9 & $\begin{array}{l}\text { Insulin-dependent diabetes mellitus } \\
\text { without complications }\end{array}$ & 7 \\
\hline $\mathrm{J} 18.0$ & Bronchopneumonia, unspecified & 16 \\
\hline J90 & $\begin{array}{l}\text { Pleural effusion, not elsewhere } \\
\text { classified }\end{array}$ & 5 \\
\hline K01.1 & Impacted teeth & 4 \\
\hline K29.7 & Gastritis, unspecified & 8 \\
\hline K52.9 & $\begin{array}{l}\text { Noninfective gastroenteritis and } \\
\text { colitis, unspecified }\end{array}$ & 11 \\
\hline K56.5 & $\begin{array}{l}\text { Intestinal adhesions [bands] with } \\
\text { obstruction }\end{array}$ & 6 \\
\hline
\end{tabular}

\begin{tabular}{clc} 
N18.9 & Chronic kidney disease, unspecified & 5 \\
N20.0 & Calculus of kidney & 11 \\
O21.0 & Mild hyperemesis gravidarum & 5 \\
O48 & Prolonged pregnancy & 9 \\
R50.9 & Fever, unspecified & 5 \\
\hline \multicolumn{2}{c}{ Total Keseluruhan Diagnosis Utama } & $\mathbf{2 5 2}$ \\
\hline
\end{tabular}

Tabel 2 Pengelompokan Prosedur Berdasarkan Diagnosis Utama

\begin{tabular}{llcc}
\hline \multicolumn{1}{c}{ Diagnosis } & \multicolumn{1}{c}{ Prosedur } & $\begin{array}{c}\text { Kode } \\
\text { Prosedur }\end{array}$ & Jumlah \\
\hline Apendicitis & Apendectomy & 47.09 & 1 \\
Ca Colon & & & 2 \\
Ca Mammae & Chemoterapy & 99.25 & 1 \\
Ca Pancreas & & & 1 \\
Ca Rectum & & 69.00 & 1 \\
Abortion Spontan & Curettage & 98.05 & 2 \\
Batu Ginjal & ESWL & 86.02 & 1 \\
Abscess & Excisi Abscess & & \\
Cutaneous & & 83.39 & 2 \\
Tumor Jaringan & Excisi Tumor & 79.02 & 1 \\
Lunak & & & 1 \\
Fraktur Clavicula & ORIF & 74.99 & 1 \\
Melahirkan Sc & & & $\mathbf{1 5}$ \\
Prolonged & SC & & \\
Pregnancy & & & \\
\hline Total Keseluruhan & & & \\
\hline
\end{tabular}

Keterangan :

ESWL : Extracorporeal Shock Wave Lithotrispy

ORIF : Open Reduction Internal fiktation

SC : sectio Caesar

\section{PEMBAHASAN}

Dari hasil yang telah didapat berdasarkan abstraksi rekam medis pasien rawat inap (Tabel 1) total keseluruhan diagnosis utama dsebanyak 252, dengan diagnosis utama terbanyak berdasarkan ICD-10 adalah Dengue Haemorrhagic Fever atau yang lebih dikenal Demam Berdarah Dengue dengan kode A91 sebanyak 17 pasien, diikuti diagnosis Bronchopneumonia dengan kode J18.0 sebanyak 16 pasien dan diagnosis malignant neoplasm colon dengan kode $\mathrm{C} 18.9$ sebanyak 14 pasien.

Penyakit Demam Berdarah Dengue (DBD) merupakan penyakit infeksi yang disebabkan oleh virus dangue dan ditularkan oleh nyamuk Aedes Aegypty. Demam Berdarah Dengue adalah penyakit menular yang disebabkan oleh virus Dengue dan ditularkan oleh nyamuk Aedes aegypti dan dapat juga ditularkan oleh Aedes albopictus, yang ditandai 
dengan : Demam tinggi mendadak, tanpa sebab yang jelas, berlangsung terus-menerus selama 2-7 hari, manifestasi perdarahan, termasuk uji Tourniquet positif, trombositopeni (jumlah trombosit $\leq 100.000$ / $\mu 1$ ), hemokonsentrasi (peningkatan hematokrit $\geq$ $20 \%$ ), disertai dengan atau tanpa perbesaran hati. (Depkes RI, 2005).

Dari penelitian sebelumnya di RSI Siti Rahmah dengan periode yang sama yaitu di bulan Maret 2017, diagnosis DHF ini tidak termasuk yang terbanyak hanya berjumlah 5 pasien. Hal ini memperlihatkan ada peningkatan dalam diagnosis DHF. Menurut profil kesehatan kota Padang (2017) menyatakan jumlah kasus DBD berfluktuasi dari tahun ketahun. Hal ini juga dipengaruhi oleh iklim dan perilaku masyarakat serta kepedulian terhadap kebersihan lingkungan. Sebagaian masyarakat juga belum paham dengan siklus penyakit DBD, sehingga terjadi keterlambatan pertolongan kesehatan, karena pasien terkadang masuk rumah sakit sudah dalam kondisi shock, yang dikenal dengan Dengue Shock Syndrome (DSS).

Bronkopneumonia (BP) juga merupakan diagnosis yang tertinggi di rumah sakit. Menurut Ramadhona (2018) dalam hasil penelitiannya di RSI Siti Rahmah menyatakan diagnosis BP mendapat urutan kedua terbanyak. Pneumonia adalah radang paru yang disebabkan oleh bakteri Streptococcus pneumoniae dengan gejala panas tinggi disertai batuk berdahak, napas cepat (frekuensi nafas $>50 \mathrm{kali} / \mathrm{menit}$ ), sesak, dan gejala lainnya (sakit kepala, gelisah dan nafsu makan berkurang). Dalam lima tahun terakhir, kota Padang selalu mengalami peningkatan posisi ditinjau dari jumlah kasus pneumonia yang ditemukanPada tahun 2015 dan 2016, Kota Padang menduduki posisi ke 6 untuk setiap tahunnya. Angka IR pneumonia Kota Padang pada tahun 2015 yaitu 20.5 dan 2016 yaitu 20.3 per 1000 jumlah balita. (Profil Kesehatan Kota Padang)

Diagnosis tertinggi ketiga yang didapat adalah malignant neoplasm colon. Kanker usus besar adalah tumor ganas yang ditemukan pada kolon atau rektum. Kanker usus besar disebut juga dengan kanker kolorektal atau kanker kolon. Kolon dan rektum merupakan bagian dari saluran pencernaan di mana fungsinya adalah untuk menghasilkan energi bagi tubuh dan membuang zat-zat yang tidak berguna. (Gontar Alamsyah, 2007:2). Sama halnya dengan kanker lainnya, awalnya kanker kolorektal bukan jaringan kanker yang membahayakan. Diperlukan sebuah proses untuk menjadi jaringan kanker yang membahayakan.

Dari tabel 2 hasil dapat dilihat prosedur terbanyak yaitu prosedur Chemoterapy dengan kode prosedur 99.25 sebanyak 5 pasien kemudian Extracorporeal shock wave lithotrispy (ESWL) dengan kode prosedur 98.5, dan Excisi Tumor dengan kode prosedur 83.39 sebanyak 2 pasien.

Salah satu bentuk penanganan kanker adalah kemoterapi. Dalam pelaksanaannya, kemoterapi menggunakan obat-obatan sitostatika. Sitostatika adalah kelompok obat (bersifat sitotoksik) yang digunakan untuk menghambat pertumbuhan sel kanker. Obat sitotoksik adalah obat yang sifatnya membunuh atau merusakkan sel-sel propaganda. Obat ini termasuk obat-obat berbahaya (OB), yaitu obat-obat yang genotoksik, karsinogenik, dan teratogenik, dan atau menyebabkan kerusakan fertilisasi, ruam kulit, kemandulan, keguguran, kecacatan bayi, risiko leukemia dan kanker lainnya. Dari 5 orang pasien yang mendapatkan prosedur kemoterapi memiliki diagnosis kanker yang berbedabeda yaitu kanker colon(2 pasien), kanker mamae (satu pasien), kanker rectum, (satu pasien), dan kanker pankreas (satu orang)

Prosedur selanjutnya yang terbanyak adalah Extracorporeal shock wave lithotrispy (ESWL). Extracorporeal Shock Wave Lithotripsy ( ESWL) banyak digunakan dalam penanganan batu saluran kencing. Prinsip dari ESWL adalah memecah batu saluran kencing dengan menggunakan gelombang kejut yang dihasilkan oleh mesin dari luar tubuh. Gelombang kejut yang dihasilkan oleh mesin di luar tubuh dapat difokuskan ke arah batu dengan berbagai cara. Setelah sampai di target tujuan yaitu di batu, gelombang kejut tadi akan melepas energinya. Diperlukan beberapa ribu kali gelombang kejut untuk memecah batu hingga menjadi pecahan-pecahan kecil, agar bisa keluar bersama air kencing tanpa menimbulkan sakit .

Prinsip kerja alat ESWL adalah menggunakan gelombang kejut. Gelombang kejut adalah gelombang tekanan yang berenergi tinggi yang dapat dialirkan melalui udara maupun air. Ketika berjalan melewati dua medium yang berbeda, energi tersebut dilepaskan, menyebabkan batu terfragmentasi. Gelombang kejut tidak menyebabkan kerusakan bila melewati substansi dengan kepadatan yang sama. Oleh karena air dan jaringan tubuh memiliki kepadatan yang sama, gelombang kejut tidak 
merusak kulit dan jaringan dalam tubuh. Batu saluran kemih memiliki kepadatan akustik yang berbeda, dan bila dikenai gelombang kejut, batu tersebut akan pecah, Setelah batu terfragmentasi, batu akan keluar dari saluran kemih (Pahira dan Pevzner, 2007).

Prosedur terakhir terbanyak adalah Eksisi tumor. Bedah eksisi adalah salah satu tindakan bedah yang membuang jaringan (tumor) dengan cara memotong. Tindakan ini dilakukan untuk berbagai tujuan antara lain pemeriksaan penunjang biopsy), pengobatan lesi jinak maupun ganas dan memperbaiki penampilan secara kosmetis. Sebelum melakukan eksisi, harus dikuasai terlebih dahulu.

\section{SIMPULAN}

Diagnosis DHF (Dengue Haemorragic Fever) termasuk yang tertinggi didapat pada periode 01-31 Maret 2018 sebanyak 17 pasien dengan kode ICD X A91. Prosedur terbanyak didapat yaitu Kemoterapi dengan kode ICD IX 99.25 sebanyak 5 prosedur dengan diagnosis kanker yang berbeda-beda.

\section{DAFTAR PUSTAKA}

Alamsyah, G. 2007. Deteksi Dini dan Penalatalaksanaan kanker Usus Besar. Fakusltas Kedokteran. Universitas sumatera Utara
Depkes RI, 2005; Undang-Undang Republik Indonesia Nomor : 23 tahun 2005 Tentang Kesehatan; Jakarta

DepKes, RI. 2006. Pedoman Pengelolaan Rekam Medis Rumah Sakit Di Indonesia. Jakarta. Direktorat Jenderal Pelayanan Medik.

Dinas Kesehatan Kota Padang. 2017. Profil Kesehatan Kota Padang.

Pahira, J. Pevzner. 2007. Pen Clinical Manual of Urologi : Nefrolithiasis. US.

Peraturan Menteri Kesehatan Republik Indonesia No.269/Menkes/Per/III/2008/tentang Rekam Medis

Soedarwoto, AD. 2000. Kombinasi bedah eksisi, skin, flaps, dan ijeksi triamsinolon asetonid intra lesi pada keloid di cuping telinga. Badan Penerbit Universitas Diponegoro. Semarang.

World Health Organization. 2010. International Statistical Classification of Diseases and Ralated Health Problem. Geneva: WHO.

.2012. International Statistical Classification of Diseases and Ralated Health Problem Clinical Modification. Geneva: WHO. 